\title{
The Impact of Executives 'Overseas Background on Chinese Enterprises' Outward Direct Investment: Based on Data From Listed Manufacturing Companies
}

\author{
Yu-Wei WANG* \\ Beijing Jiaotong University, Beijing, China \\ Email: 17120552@bjtu.edu.cn
}

Keywords: foreign direct investment, executives overseas background, innovation

\begin{abstract}
The development of OFDI is of great significance to China's manufacturing industry structure and manufacturing enterprises themselves. How to carry out higher-quality foreign direct investment has become a question worthy of attention. This article takes the listed companies of Shanghai and Shenzhen A-share manufacturing companies in China from 2009 to 2018 as research objects, studies the impact of overseas background of corporate executives on foreign direct investment of enterprises, analyzes the direct and indirect channels of the impact, and further examine the differences in different types of overseas backgrounds. The study found that companies with overseas background are more likely to make direct foreign investment. Executives with overseas work experience are more likely to promote companies' direct foreign investment than those executives who have overseas learning background.
\end{abstract}

\section{Introduction}

As the main body of a country's real economy, manufacturing industry is an important indicator of the comprehensive strength of a country. The development of foreign direct investment in manufacturing industries and the transfer of excess capacity are important for optimizing China's industrial structure and promoting the coordinated and healthy development of China's economy. significance. As more and more overseas personnel choose to return to China for employment, returnees will learn and train abroad and work out. After entering the corporate executive team, it will bring important changes to corporate decisions. By analyzing the relationship between the two, we can further recognize the impact of the characteristics of the executive team on business operations and more factors that affect the outward direct investment of China's manufacturing industry, and then select our senior management team and provide manufacturing companies with "going out" suggest.

\section{Literature References and Research Hypothesis}

\subsection{Influence of executives' overseas background on OFDI}

In terms of foreign direct investment, compared with executives with no overseas background, the direct impact of executives with an overseas background on the OFDI of the company is reflected in the following: First, returnee executives have a cognitive advantage of the overseas environment. Overseas study or work experience often makes returnees have a wealth of international business knowledge and business ideas that are easy to integrate into the international environment, and better understand the needs of the international market, so they are more inclined to invest abroad[1]. The background has formed an extensive overseas relationship network, which has provided enterprises with a variety of overseas information access channels, which helps companies to find investment opportunities, identify high-quality investment targets, and facilitate international cooperation[2].Guan has higher corporate governance capabilities and is better at managing overseas subsidiaries[3]. Fourthly, due to the existence of the "outsider disadvantage" effect, overseas returnees' directors with overseas backgrounds tend to study abroad and work experience abroad, and have weaker connections with the domestic. They will seek to make use of overseas social networks 
by promoting the internationalization of enterprises.[4].

Based on this, put forward Hypothesis 1: The overseas background of executives directly promotes enterprises' direct foreign investment.

\subsection{Heterogeneity analysis of executives' overseas background}

Executives' overseas background is broadly divided into study and work. Studying abroad has been the main way for people to go abroad. Therefore, returnees are naturally considered to have received high-quality overseas teaching, mastered advanced professional knowledge, and have a broader vision. These unique advantages undoubtedly identify corporate investment opportunities and business management problems. The conquest played an important role. Although the higher the education level of returnee executives, the closer they are to the world's top technology, and the more they can promote the technological progress of enterprises, the practical experience is also very important for enterprises' outward direct investment behavior[5] . Executives with overseas work experience are more familiar with the operating models of overseas companies. They can rely on the practical experience of working in foreign companies to cut down on physical meetings and learn advanced foreign management, establish an extensive international relationship network, and acquire more advanced professional skills and governance. Level, more able to apply it to the management practice of the company they perform, combining the most advanced theoretical knowledge from overseas with international investment practice experience, to better judge and control new market opportunities, and for enterprises Make the most appropriate development judgement[6].

Based on this, this article proposes Hypothesis 2: Compared with overseas learning experiences, the overseas work experience of executives has a greater impact on the company's outward direct investment.

\section{Equations and Data Sources}

Using the data of listed companies in China's manufacturing enterprises, to study whether the characteristics of executives with overseas background affect the OFDI of enterprises, and use panel models to test. The construction model is shown in equation (1):

$$
\text { OFDI }_{i t}=\beta_{0}+\beta_{1} \text { overseas }_{i t}+\beta_{2} \text { Controls }_{i t}+\varepsilon_{i t}
$$

Among them, $i$ represents the industry breakdown under the manufacturing industry, and $t$ represents the year. $O F D I_{i t}$ represents foreign direct investment, of which foreign direct decision-making is represented by $O F D I_{-} J C_{i t}$ and measured by the number of newly established subsidiaries of the enterprise. The scale of foreign direct investment is represented by $O F D I_{-} G M_{i t}$, which is measured by the number of newly established enterprises in a certain year. Foreign direct investment is represented by overseas, if the company has executives or directors with overseas work or study experience in that year, the value is 1 ; otherwise, it is 0 , and the overseas background strength is expressed as overseas_ $b$. The number of executives with overseas background accounts for the total number of board members To measure. Controls contains the control variables. Considering the influence of the characteristics of the senior management team on OFDI, this paper selects the variables at the enterprise and senior management team levels. At the enterprise level, size indicates the size of the company, measured by the total assets of the company that year; age indicates the number of years of establishment of the enterprise, measured by the number of years from the establishment of the company to the current year; structure indicates the structure of the assets, measured by dividing fixed assets by total assets; gap indicates The salary gap is the difference between the average of the top three executives in the salary and the average of the rest of the executives; power refers to equity incentives, which are represented by dummy variables, and refer to whether the executives have received equity incentives.

In this paper, the listed companies of Shanghai and Shenzhen A-share manufacturing companies from 2009 to 2018 were selected as the research objects, and the preliminary sample was screened. 
Finally, 1,359 listed companies and 1,044 financial observations were obtained. The corporate governance and financial data involved in this article are from Wind and CSMAR. Among them, the overseas background data of senior executives was manually collected based on the resumes of senior executives of listed companies in CSMAR and overseas background data. Important missing values were filled in through Internet data. Winsorize processing was performed on all continuous variables up and down $1 \%$. Table 1 shows a descriptive statistical analysis of the main variables.

Table 1 Sample Descriptive Statistics

\begin{tabular}{l|ccccc}
\hline \multicolumn{1}{c|}{ Variable } & \multicolumn{1}{c}{ Mean } & Standard & Deviation & Maximum & Observation \\
\hline OFDI_JC & 0.572 & 0.495 & 1 & 0 & 10044 \\
OFDI_GM & 0.512 & 1.091 & 8 & 0 & 9953 \\
overseas & 0.568 & 0.495 & 1 & 0 & 10044 \\
overseas_b & 0.158 & 0.204 & 1.222 & 0 & 9609 \\
size & 22.023 & 1.147 & 25.595 & 19.693 & 9842 \\
age & 16.341 & 5.179 & 34 & 6 & 9866 \\
structure & 0.224 & 0.129 & 0.606 & 0.015 & 9842 \\
gap & 12.883 & 0.748 & 15.014 & 10.848 & 9521 \\
power & 0.073 & 0.259 & 1 & 0 & 10044 \\
\hline
\end{tabular}

This paper uses stata15.0 software to perform regression analysis on the overseas background of executives and the outward direct investment and scale of listed companies in manufacturing.

In the choice of regression method, taking into account the characteristics of the dependent variable, when a company's foreign direct investment decision ( $O F D I_{-} J C$ ) is used as the dependent variable, its characteristic is a categorical variable that takes 0 or 1 , using logit regression. When the dependent variable is outward direct investment, the scale ( $O F D I_{-} G M$ ) is characterized by continuous variables, and this paper uses a multiple linear regression model.

\subsection{Test of the influence of overseas background on OFDI}

Test Hypothesis 1 according to model (1). The regression results are shown in Table 2. Columns (1) and (3) report the regression results using whether the company employs executives with overseas background (overseas) as independent variables. The results show that regardless of whether the company is conducting outbound direct investment or the size of the company's outward direct investment, the regression coefficients of overseas are significantly positive and significant at the level of $1 \%$, which indicates that the employment of executives with overseas background It has increased the possibility of foreign direct investment of enterprises and helped to expand the scale of foreign direct investment. Specifically speaking, the impact of OFDI on the decision-making of an enterprise with an overseas background is greater than the scale of OFDI, that is, it is more helpful to promote the decision-making of foreign direct investment. This may be because the knowledge and culture of senior executives overseas has changed the returneering executives risk-bearing consciousness, which has affected their perception of risks in the process of foreign direct investment. Compared to the West, the East is more conservative in thinking and more evasive in the face of risks. Therefore, executives with an overseas background are more willing to accept new challenges than those who have grown up locally. Continue to adapt to the new environment, which will have an important impetus for companies to implement "go global" strategic decisions. Regression is based on the proportion of executives from overseas background in the board of directors as independent variables. Columns (2) and (4) provide relevant results. The results support the promotion of OFDI by the overseas background of executives. The above results provide supporting evidence for Hypothesis 1 , that the overseas background of executives is indeed conducive to promoting foreign direct investment by enterprises. 


\subsection{Heterogeneity test of different types of executives' overseas background affecting OFDI}

In order to further examine the impact of "returnee" executives on the company's internationalization strategy, we further refined the "returnee" executives into executives with overseas work experience and overseas education experience according to the type of overseas experience, and inspected different overseas backgrounds. Are there any differences in the impact of executives on corporate direct investment abroad?

Table 2 Benchmark Regression.

\begin{tabular}{|c|c|c|c|c|}
\hline \multirow{2}{*}{ Explained variable } & \multirow{2}{*}{$\begin{array}{l}\text { OFDI_JC } \\
\text { (1) }\end{array}$} & \multicolumn{3}{|c|}{ OFDI_GM } \\
\hline & & (2) & $(3)$ & $(4)$ \\
\hline overseas & $\begin{array}{l}0.3548^{* * * *} \\
(0.053)\end{array}$ & & $\begin{array}{l}0.1244 * * * \\
(0.025)\end{array}$ & \\
\hline overseas_b & & $\begin{array}{l}0.2861^{* *} \\
(0.119)\end{array}$ & & $\begin{array}{l}0.1108^{* *} \\
(0.054)\end{array}$ \\
\hline size & $0.4839^{* *}$ & $0.4850^{* * *}$ & $0.1721^{* *}$ & $0.1755^{* * *}$ \\
\hline age & $\begin{array}{l}0.0326^{* * *} \\
(0.005)\end{array}$ & $\begin{array}{l}0.0308^{* * *} \\
(0.005)\end{array}$ & $\begin{array}{l}-0.0119^{* * * *} \\
(0.002)\end{array}$ & $\begin{array}{l}-0.0122^{* * *} \\
(0.002)\end{array}$ \\
\hline structure & $\begin{array}{l}0.6085^{* *} \\
(0.210)\end{array}$ & $\begin{array}{l}0.5946^{* *} \\
(0.211)\end{array}$ & $\begin{array}{l}-0.3544^{*} \\
(0.095)\end{array}$ & $\begin{array}{l}-0.3296 \\
(0.095)\end{array}$ \\
\hline gap & $\begin{array}{l}0.2834 * * * \\
(0.038)\end{array}$ & $\begin{array}{l}0.3248^{* * * *} \\
(0.038)\end{array}$ & $\begin{array}{l}0.1096^{* * * *} \\
(0.017)\end{array}$ & $\begin{array}{l}0.1180^{* * * *} \\
(0.017)\end{array}$ \\
\hline power & $\begin{array}{l}0.3974 * * \\
(0.097)\end{array}$ & $\begin{array}{l}0.3870^{* *} \\
(0.098)\end{array}$ & $\begin{array}{l}0.2030^{* *} \\
(0.043)\end{array}$ & $\begin{array}{l}0.2126^{* *} \\
(0.043)\end{array}$ \\
\hline Cons $\tan t$ & $\begin{array}{l}-15.9426^{* * *} \\
(0.665)\end{array}$ & $\begin{array}{l}-16.3119^{* * *} \\
(0.664)\end{array}$ & $\begin{array}{l}-4.2555^{* * * *} \\
(0.278)\end{array}$ & $\begin{array}{l}-4.3746^{* * * *} \\
(0.277)\end{array}$ \\
\hline Observations & 9,030 & 8,881 & 8,957 & 8,811 \\
\hline
\end{tabular}

Note: $* * *, * *$, and $*$ indicate that they are significant at the levels of $1 \%, 5 \%$, and $10 \%$, respectively. The numbers in parentheses are the corresponding standard errors (both sides).

First, according to whether or not you have overseas work experience, to further analyze the returnee characteristics of the company, we constructed the following variables: executives' overseas work experience dummy variable (work_if), if the company has only overseas executives or directors in the year, the value is 1 , Otherwise it is 0 ; the dummy variable for senior executives' overseas learning experience (study_if ) is set to 1 if the company has only executives or directors with overseas learning experience in the current year, otherwise it is 0 . In order to test the stability of the results, construct continuous value variables at the same time: the proportion of "working" returnees executives ( work_b ), measured by the proportion of executives with overseas work experience in the total number of board members; "learning" returning executives ( study_b), Measured by the proportion of executives with overseas learning experience in the total number of board members. To test Hypothesis 2, establish the following model for testing:

$$
\begin{gathered}
\text { OFDI }_{i t}=\beta_{0}+\beta_{1} \text { work }_{i t}+\beta_{2} \text { Controls }_{i t}+\varepsilon_{i t} \\
\text { OFDI }_{i t}=\beta_{0}+\beta_{1} \text { study }_{i t}+\beta_{2} \text { Controls }_{i t}+\varepsilon_{i t}
\end{gathered}
$$

The regression results of OFDI decision-making from overseas backgrounds are shown in Table 3 . From the results, it can be clearly found that the overseas work experience of executives has a greater impact on the OFDI of the company, all of which passed the 5\% significance test. The overseas learning experience of the executives also has a positive impact on the OFDI of the company, but the coefficient value and significance Are far less than the former. The above results show that there are differences in the impact of different types of overseas experience on the OFDI of a company. Compared with overseas learning experiences, the overseas working experience of corporate executives has played a more prominent role in the OFDI decision making of enterprises, prompting companies to make decisions on foreign direct investment. This shows that executives with overseas 
work experience can combine the most advanced theoretical knowledge abroad with international investment practice experience to better judge and control new market opportunities and make the most timely development judgment for the enterprise.

Table 3 The Impact of Different Types of Overseas Backgrounds on OFDI Decisions

\begin{tabular}{|c|c|c|c|c|}
\hline \multirow{2}{*}{$\begin{array}{c}\text { Explanatory } \\
\text { variables }\end{array}$} & \multicolumn{4}{|c|}{$O F D I \_J C$} \\
\hline & (1) & (2) & (3) & (4) \\
\hline work_if & $\begin{array}{c}0.0257^{* *} \\
(0.047)\end{array}$ & & & \\
\hline work_b & & $\begin{array}{c}0.4209^{* *} \\
(0.190)\end{array}$ & & \\
\hline study_if & & & $\begin{array}{l}0.0002 \\
(0.047)\end{array}$ & \\
\hline study_b & & & & $\begin{array}{c}0.3415^{*} \\
(0.213)\end{array}$ \\
\hline size & $\begin{array}{c}0.4772 * * \\
(0.025)\end{array}$ & $\begin{array}{c}0.4796^{* * *} \\
(0.025)\end{array}$ & $\begin{array}{c}0.4774 * * \\
(0.025)\end{array}$ & $\begin{array}{c}0.4784 * * \\
(0.025)\end{array}$ \\
\hline age & $\begin{array}{c}0.0212 * * * \\
(0.005)\end{array}$ & $\begin{array}{c}0.0215 * * * \\
(0.005)\end{array}$ & $\begin{array}{c}0.0212^{* * *} \\
(0.005)\end{array}$ & $\begin{array}{c}0.0214 * * * \\
(0.005)\end{array}$ \\
\hline structure & $\begin{array}{c}0.6246^{* *} \\
(0.195)\end{array}$ & $\begin{array}{c}0.6279 * * \\
(0.196)\end{array}$ & $\begin{array}{c}0.6265^{*} \\
(0.195)\end{array}$ & $\begin{array}{c}0.6294 * * \\
(0.196)\end{array}$ \\
\hline gap & $\begin{array}{c}0.3091 * * * \\
(0.034)\end{array}$ & $\begin{array}{c}0.3116^{* * * *} \\
(0.034)\end{array}$ & $\begin{array}{c}0.3093 * * * \\
(0.034)\end{array}$ & $\begin{array}{c}0.3115^{* * * *} \\
(0.034)\end{array}$ \\
\hline power & $\begin{array}{c}0.4006^{* * *} \\
(0.094)\end{array}$ & $\begin{array}{c}0.3915^{* * *} \\
(0.094)\end{array}$ & $\begin{array}{c}0.4008^{* *} \\
(0.094)\end{array}$ & $\begin{array}{c}0.3936^{* *} \\
(0.094)\end{array}$ \\
\hline Cons $\tan t$ & $\begin{array}{c}-15.8251^{* * *} \\
(0.601)\end{array}$ & $\begin{array}{c}-15.9315^{* * *} \\
(0.604)\end{array}$ & $\begin{array}{c}-15.8252^{* * *} \\
(0.602)\end{array}$ & $\begin{array}{c}-15.9056^{* * *} \\
(0.603)\end{array}$ \\
\hline Observations & 9,714 & 9,647 & 9,714 & 9,647 \\
\hline
\end{tabular}

Note: $* * *, * *$, and $*$ indicate that they are significant at the levels of $1 \%, 5 \%$, and $10 \%$, respectively. The numbers in parentheses are the corresponding standard errors (both sides). 
Table 4 The Impact of Different Types of Overseas Backgrounds on OFDI Scale

\begin{tabular}{|c|c|c|c|c|}
\hline \multirow{2}{*}{$\begin{array}{l}\text { Explanatory } \\
\text { variables }\end{array}$} & \multicolumn{4}{|c|}{ OFDI_GM } \\
\hline & (1) & (2) & (3) & (4) \\
\hline work_if & $\begin{array}{l}0.0810^{*} \\
(0.043)\end{array}$ & & & \\
\hline work_b & & $\begin{array}{c}0.5146^{* * *} \\
(0.115)\end{array}$ & & \\
\hline study_if & & & $\begin{array}{l}0.0092 \\
(0.043)\end{array}$ & \\
\hline$s t u d y \_b$ & & & & $\begin{array}{c}0.3220^{* * *} \\
(0.130)\end{array}$ \\
\hline size & $\begin{array}{c}0.3265^{* *} \\
(0.020)\end{array}$ & $\begin{array}{c}0.3293 * * * \\
(0.020)\end{array}$ & $\begin{array}{c}0.3269 * * * \\
(0.020)\end{array}$ & $\begin{array}{c}0.3273 * * * \\
(0.020)\end{array}$ \\
\hline age & $\begin{array}{l}0.0054 \\
(0.004)\end{array}$ & $\begin{array}{l}0.0052 \\
(0.004)\end{array}$ & $\begin{array}{l}0.0054 \\
(0.004)\end{array}$ & $\begin{array}{r}0.005 \\
(0.004)\end{array}$ \\
\hline structure & $\begin{array}{c}-0.7758^{*} \\
(0.171)\end{array}$ & $\begin{array}{c}-0.7585^{* *} \\
(0.171)\end{array}$ & $\begin{array}{c}-0.7708^{* *} \\
(0.171)\end{array}$ & $\begin{array}{c}-0.7595^{* * *} \\
(0.171)\end{array}$ \\
\hline gap & $\begin{array}{c}0.1439 * * * \\
(0.029)\end{array}$ & $\begin{array}{c}0.1423 * * * \\
(0.029)\end{array}$ & $\begin{array}{c}0.1447 * * * \\
(0.029)\end{array}$ & $\begin{array}{c}0.1447^{* *} \\
(0.029)\end{array}$ \\
\hline power & $\begin{array}{c}0.2846^{* *} \\
(0.081)\end{array}$ & $\begin{array}{c}0.2809 * * \\
(0.081)\end{array}$ & $\begin{array}{c}0.2848^{* *} \\
(0.081)\end{array}$ & $\begin{array}{c}0.2814^{* * *} \\
(0.081)\end{array}$ \\
\hline Cons $\tan t$ & $\begin{array}{c}-7.6646^{* * * *} \\
(0.468)\end{array}$ & $\begin{array}{c}-7.7047 * * * \\
(0.468)\end{array}$ & $\begin{array}{c}-7.6655^{* * *} \\
(0.468)\end{array}$ & $\begin{array}{c}-7.7112 * * * \\
(0.468)\end{array}$ \\
\hline Observations & 9,714 & 9,647 & 9,714 & 9,647 \\
\hline
\end{tabular}

Note: ***, **, and * indicate that they are significant at the levels of $1 \%, 5 \%$, and $10 \%$, respectively. The numbers in parentheses are the corresponding standard errors (both sides).

The regression results of the influence of overseas background on the scale of OFDI are shown in Table 4. The overseas work and study experience of executives have a positive impact on the OFDI scale of enterprises. Similarly, the overseas work experience variable has a greater coefficient value and significance than the overseas study variable, indicating that the overseas work experience of executives has a significant impact on the size of OFDI. The impact should be stronger than the learning experience. "Working" returnee executives rely on advanced management experience, higher risk control capabilities, and strong sense of responsibility to make decisions more robust and reliable, and promote the continued occurrence of foreign direct investment.

Compared with whether an enterprise employs returnee executives, the index of returnee executives has a better explanation of the problem. It has passed the $1 \%$ significance test and has a large coefficient value, indicating that as more executives join the management team , The company's ability to acquire overseas information and resources has been improved, which has broadened the path for companies to enter overseas markets. At the same time, the proportion of executives facing overseas returnees has increased, and the number of interactions and interactions with local executives has increased, which will increase the executive team. The degree of consistency of ideas and cognitions helps companies to seize overseas investment opportunities. Thus, Hypothesis 2 is verified.

\section{Summary}

This article uses China's 2009-2018 Shanghai and Shenzhen A-share listed companies as a sample to test the influence of overseas background of executives on the decision-making behavior of enterprises' direct foreign investment. The study found that executives' overseas background can promote foreign direct investment. In terms of the impact on OFDI, the overseas background of executives has a greater impact on OFDI decision-making than the scale of OFDI. In terms of 
heterogeneity, executives with overseas work experience are more capable of promoting foreign direct investment by enterprises than executives with overseas learning background.

This article not only enriches the relevant literature on the influencing factors of China's foreign direct investment, but also provides an important reference for improving China's overseas talent introduction policy and for listed companies to explore overseas markets.

\section{References}

[1] Zhang Ye. Whether the overseas background of senior management is conducive to foreign direct investment by enterprises. Macroeconomic Research, 6 (2015): 107-116,151.

[2] Pruthi S. Social ties and venture creation by returneeentrepreneurs [J]. International Business Review, 23 (2014): 1139-1152.

[3] Dai Yunhao, Kong Dongmin. Whether the overseas experience of senior executives can improve corporate investment efficiency. World Economy, J. Sci. Commun. 40 (2017): 168-192.

[4] Chen Jian, Liu Xulin, Qiu Yimin, Gao Yuchen. The disadvantages of foreigners in overseas returnees and the adjustment of knowledge capital. Research in Science of Science, J. Sci. Commun. 35 (2017): 1348-1358.

[5] Li Xiao, Hua Guihong. Can the overseas background of executives promote Chinese companies to "go global" ?- Based on PSM estimates of A-share listed companies in China. Industrial Economics Review (Shandong University), J. Sci. Commun. 17 (2018): 123-145.

[6] Jianbo Song, Wenwen, Wang Dehong. Can returnee executives promote corporate risk-takingEmpirical evidence from Chinese A-share listed companies. Finance and Trade Economy J. Sci. Commun., 12 (2017): 111-126. 